\title{
Cystic Fibrosis Fibroblasts Respond Normally to Isoproterenol
}

\author{
JAMES B. KURZ ${ }^{(16)}$ and JOHN P. PERKINS \\ Department of Pharmacology, The University of North Carolina, Chapel Hill, North Carolina, USA
}

\begin{abstract}
Summary
Thirteen cystic fibrosis and 12 normal strains of skin fibroblasts obtained from the Institute for Medical Research were compared for their degree of production of cyclic adenosine $3^{\prime}: 5^{\prime}$-monophosphate in response to isoproterenol and prostaglandin $E_{1}$. There were no significant differences in their quantitative responses in content of cyclic AMP at two different times whether these cells were growing exponentially or were already confluent. All strains responded similarly to the presence of two types of phosphodiesterase inhibitor. The averaged initial rates of the response to isoproterenol in exponentially growing cells were also similar for the two sets of strains. Although response differed greatly between strains, the response of each strain was relatively reproducible.
\end{abstract}

\section{Speculation}

It appears that cystic fibrosis skin fibroblasts and normal skin fibroblasts are equally sensitive to isoproterenol. The likely explanation for a previous observation of a 3-fold higher response to isoproterenol is that an improbable selection of the five cystic fibrosis strains and the five normal strains occurred.

The observation by Buchwald (1) that skin fibroblasts taken from five boys afflicted with cystic fibrosis (CF) produced more cyclic adenosine $3^{\prime}: 5^{\prime}$-monophosphate (cyclic AMP) in response to isoproterenol than did strains of fibroblasts taken from normal young males prompted us to test this correlation on larger samplings of both subject types. We report here evidence [in accord with a later report by Buchwald and Mapleson (2)] that fibroblasts have a wide variation in their response to isoproterenol, but this response is not affected by the presence of cystic fibrosis in the donor.

\section{MATERIALS AND METHODS}

The fibroblasts used in these experiments were all from human skin and were obtained from the Institute for Medical Research, Camden, NJ. Strains used here were originated by investigators outside of the Institute except for normal strains 316 and 1582. Strains were grown at the Institute in the various media used by the originator (without antibiotics) and frozen in the same media plus $10 \%$ glycerol. Ampules of desired strains are thawed upon request, and cells in exponential growth are shipped by air (at room temperature) in $25 \mathrm{~cm}^{2}$ flasks completely filled with medium. The age, sex, and passage number, as stored at the Institute are presented for each strain in Table 1. Strains are unrelated except that 1013 and 1014 came from brothers, 1957 and 1959 came from brothers, and 1651 and 1652 came from sisters. After reception, the strains were passaged 2 to 7 times at 1:4 splits before being harvested during exponential growth and frozen for future use. For experiments, cells were thawed in a $37^{\circ} \mathrm{C}$ water bath and quickly placed in $10 \mathrm{ml}$ of growth medium. After 2 to 5 days, they were passaged once to $2500 \mathrm{cells} / \mathrm{cm}^{2}$, harvested during exponential growth ( 3 to 4 days), and planted again at 2500 cells $/ \mathrm{cm}^{2}$ to begin experiments. The usual growth medium was Eagle's minimal essential medium (MEM) plus $1 \mathrm{mM}$ pyruvate, $0.2 \mathrm{mM}$ asparagine, and $0.2 \mathrm{mM}$ serine (7) and 10 to $20 \%$ fetal calf serum. In the experiments of Table I we used $\alpha$ medium with $15 \%$ fetal calf serum in analogy with Buchwald (1). Cells were freed from the plate for passaging by incubation at room temperature in $0.05 \%$ trypsin for 5 to $10 \mathrm{~min}$ followed by rigorous pipetting in growth medium. This allowed quantitative release for all strains except GM323. The trypsin was dissolved in an isotonic salts solution (GHCKS) brought to $\mathrm{pH} 7.4$ with sodium hydroxide. Each liter of GHCKS contained 2 g glucose, $4.77 \mathrm{~g}$ 4-(2-hydroxyethyl)-1piperazineethanesulfonic acid (HEPES) $(20 \mathrm{mM}), 3 \mathrm{~g}$ sodium citrate, $0.2 \mathrm{~g}$ potassium chloride, $6.37 \mathrm{~g}$ sodium chloride, and 0.01 $\mathrm{g}$ phenol red. Cells in $100 \mathrm{~mm}$ dishes were rinsed once and then incubated with $3 \mathrm{ml}$ trypsin solution. In preparation for freezing, however, cells were incubated in a film of trypsin in a draft-free area. They were then resuspended in 70\% Eagle's MEM, $20 \%$ fetal calf serum, and $10 \%$ dimethyl sulfoxide and frozen slowly over liquid nitrogen in a Union Carbide Biological Freezer BF5.

For experiments, cells were grown in 24-well plates (Costar) in $1 \mathrm{ml}$ of growth medium at $37^{\circ} \mathrm{C}$ in $5 \% \mathrm{CO}_{2}$. In preparation for stimulation of the cells, we set the plates in a $37^{\circ} \mathrm{C}$ water bath and replaced the growth medium with warmed HEPES-buffered Eagle's MEM (without serum) containing the desired concentration of freshly dissolved agonist. At the appropriate times, this medium was aspirated and replaced with 5\% trichloroacetic acid (TCA). The TCA supernatants were placed onto Pasteur pipette columns containing about $4 \mathrm{~cm}$ of Dowex 50 . The columns were rinsed with $1.5 \mathrm{ml} 0.1 \mathrm{~N} \mathrm{HCl}$ followed by $1.5 \mathrm{ml} \mathrm{H}_{2} \mathrm{O}$. The cyclic AMP fraction was collected in the next $3.0 \mathrm{ml} \mathrm{H}_{2} \mathrm{O}$. Cyclic AMP standards were also run over columns $(0.1$ to 50 pmoles in $1 \mathrm{ml}$ $5 \%$ TCA). Eluted samples and standards were buffered by adding $0.1 \mathrm{ml}$ of $1.5 \mathrm{M}$ sodium acetate with $0.15 \mathrm{M} \mathrm{CaCl}_{2}$ (15) at $\mathrm{pH} 4.75$. Cyclic AMP was determined by radioimmunoassay (8). Aliquots of from 0.05 to $0.25 \mathrm{ml}$ were acetylated with $0.005 \mathrm{ml}$ of a $2: 1$ fresh mixture of triethylamine:acetic anhydride (15). To this was added $0.05 \mathrm{ml}$ of ${ }^{125}$ I-tyrosylmethylester of succinyl cyclic AMP $(10,000$ to $20,000 \mathrm{cpm}$; specific activity, $>150 \mathrm{Ci} / \mathrm{mmole})$ and 0.1 $\mathrm{ml}$ of a 1:5000 dilution of cyclic AMP antibody from rabbit. These additions were dissolved in $0.05 \mathrm{M}$ sodium acetate and $5 \mathrm{mM}$ $\mathrm{CaCl}_{2}$ at $\mathrm{pH} 4.75$. The antibody solution also contained $30 \mathrm{mg} / \mathrm{ml}$ bovine serum albumin, Cohn fraction 5 . The samples were incubated at $4^{\circ} \mathrm{C}$ overnight, mixed with $2 \mathrm{ml}$ of cold $70 \%$ ethanol, and centrifuged at $2000 \times \mathrm{g}$ at $0^{\circ} \mathrm{C}$ for $20 \mathrm{~min}$. The supernatant was aspirated, and the pellet was counted with a Searle gamma counter for $5 \mathrm{~min}$. The pellet lost about $10 \%$ of its counts to the atmosphere if it was allowed to dry. We thus added $0.2 \mathrm{ml} \mathrm{H}_{2} \mathrm{O}$ to each tube to prevent drying during the counting period.

Protein was determined on TCA-precipitable residue by the method of Lowry et al. (10) using bovine serum albumin as a standard. Cells were counted on a Particle Data Celloscope.

The chemicals used and their sources were: media powder, trypsin, fetal calf serum from Grand Island Biological Co; fetal calf serum also from Microbiological Associates; HEPES buffer, pyruvate, $d, l$-isoproterenol, prostaglandin $\mathrm{E}_{1}\left(\mathrm{PGE}_{1}\right)$, bovine se- 
Table 1. Accumulation of cyclic AMP by cells at confluency

\begin{tabular}{ccccccc}
\hline & & & & \multicolumn{2}{c}{ Intracellular cyclic } \\
\cline { 5 - 6 } & Passage & & & \multicolumn{2}{c}{ AMP $^{1}$} \\
\cline { 4 - 7 } Strains & From & Age of & & Sex & Ro20-1724 & IBMX \\
\hline
\end{tabular}

CF strains

$\begin{array}{lr}\text { CF } & 142 \\ \text { CF } & 1013 \\ \text { CF } & 1014 \\ \text { CF } & 768 \\ \text { CF } & 770 \\ \text { CF } & 998 \\ \text { CF } & 1957 \\ \text { CF } & 1959 \\ \text { CF } & 1707 \\ \text { CF } & 999 \\ C F & 997 \\ C F & 851 \\ \text { CF } & 1011 \\ \text { Mean }\end{array}$

$\begin{array}{cc}3 & 14 \\ 9 & 11 \\ 8 & 13 \\ 3 & 13 \\ 2 & 19 \\ 8 & 4 \\ 6 & 11 \\ 4 & 10 \\ 10 & 9 \\ 14 & 13 \\ 8 & 10 \\ 7 & 22 \\ 10 & 7 \\ 7.1 & 12.0\end{array}$

$\begin{array}{lll}\text { M } & 0.61 & 0.40 \\ \text { M } & 0.15 & 0.10 \\ \text { M } & 0.16 & 0.14 \\ \text { M } & 1.04 & 0.66 \\ \text { M } & 0.45 & 0.52 \\ \text { M } & 1.33 & 0.67 \\ \text { M } & 0.50 & 0.21 \\ \text { M } & 0.63 & 0.47 \\ \text { F } & 2.41 & 1.80 \\ \text { F } & 1.81 & 1.24 \\ \text { M } & & \\ \text { M } & & \\ \text { M } & & \\ & 0.91 & 0.62 \\ & 0.23 & 0.17\end{array}$

Control strains

\begin{tabular}{lrlrlll}
$\mathrm{N}$ & 316 & 3 & 12 & $\mathrm{M}$ & 0.53 & 0.41 \\
$\mathrm{~N}$ & 323 & 4 & 11 & $\mathrm{M}$ & 0.37 & 0.44 \\
$\mathrm{~N}$ & 498 & 4 & 3 & $\mathrm{M}$ & 0.56 & 0.22 \\
$\mathrm{~N}$ & 499 & 7 & 8 & $\mathrm{M}$ & 1.59 & 0.94 \\
$\mathrm{~N}$ & 2037 & 8 & 13 & $\mathrm{M}$ & 0.44 & 0.20 \\
$\mathrm{~N}$ & 495 & 6 & 29 & $\mathrm{M}$ & 0.75 & 0.40 \\
$\mathrm{~N}$ & 1582 & 5 & 11 & $\mathrm{~F}$ & 1.14 & 0.61 \\
$\mathrm{~N}$ & 1651 & 7 & 13 & $\mathrm{~F}$ & 1.00 & 1.11 \\
$\mathrm{~N}$ & 1652 & 7 & 11 & $\mathrm{~F}$ & 1.07 & 0.41 \\
$\mathrm{~N}$ & 500 & 8 & 10 & $\mathrm{M}$ & & \\
$\mathrm{N}$ & 409 & 8 & 7 & $\mathrm{M}$ & & \\
$\mathrm{N}$ & 497 & 8 & 4 & $\mathrm{M}$ & & \\
$\mathrm{Mean}$ & 6.2 & 11.0 & & 0.83 & 0.53 \\
S.E. & & & & 0.13 & 0.10 \\
\hline
\end{tabular}

' nmoles of cyclic AMP per $10^{6}$ cells. Cells were seeded in $\alpha$ medium with $15 \%$ fetal calf serum at 5000 per well of area $2.0 \mathrm{~cm}^{2}$ and challenged

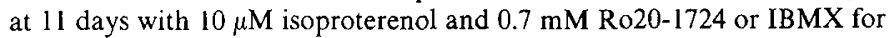
$15 \mathrm{~min}$. Values are the averages of triplicate samples.

rum albumin from Sigma Chemical Co., HEPES buffer also from Research Organics; asparagine and serine from Calbiochem; glucose, copper sulfate, potassium sodium tartrate, sodium citrate, potassium chloride, and phenol red from J. T. Baker Chemical Co.; sodium chloride, dimethyl sulfoxide, Folin-Ciocalteau reagent, and sodium carbonate from Fisher Chemicals; 2-isobutyl1-methyl xanthine (IBMX) from Aldrich Chemical Co.; acetic anhydride and triethylamine from Eastman Organic Chemicals; Dowex 50W-X8 from Bio-Rad Laboratories; ${ }^{125}$ I-labeled antigen as a gift from Dr. Alton Steiner; Ro20-1724 as a gift from Dr. H. Sheppard of Hoffman-LaRoche.

\section{RESULTS}

\section{ACCUMULATION OF CYCLIC AMP AT CULTURE CONFLUENCY}

Buchwald's (1) principal method of comparison of five $\mathrm{CF}$ and five normal strains was to measure the amount of cyclic AMP accumulated in $15 \mathrm{~min}$ by confluent cells in response to $10 \mu \mathrm{M}$ isoproterenol and $0.7 \mathrm{mM}$ RO20-1724. We carried out a similar comparison with nine normal strains and $10 \mathrm{CF}$ strains (Table 1). We tested the two phosphodiesterase inhibitors, Ro20-1724 and IBMX, at $0.7 \mathrm{mM}$. In the presence of either inhibitor, the response varied greatly between strains. With Ro20-1724, the cyclic AMP per $10^{6}$ cells ranged from 0.15 to 2.41 nmoles for CF strains and
0.37 to 1.59 nmoles for the normal strains. The difference between the average responses for CF and normal strains was small and insignificant $(P>0.6)$ using either inhibitor.

We also measured the cyclic AMP accumulated per $10^{6}$ cells without phosphodiesterase inhibitors at $5 \mathrm{~min}$ and found $0.24 \pm$ 0.10 nmoles $( \pm$ S.E.) for $\mathrm{CF}$ and $0.33 \pm 13$ nmoles for normal cells. At $15 \mathrm{~min}$, we found $0.12 \pm 0.07$ nmoles for CF and $0.07 \pm$ 0.02 nmoles for normal cells. The lowering by a factor of about 10 of the $15 \mathrm{~min}$ response due to lack of phosphodiesterase inhibitors is similar to the observation of Buchwald (1) on two normal and two $C F$ strains at confluence. These differences between $C F$ and normal strains at 5 and $15 \mathrm{~min}$ were again insignificant $(P>0.5)$.

Although it is always difficult to repeat the protocol of others exactly, we are aware of two differences worth mentioning: (1) we began our cultures at $2500 / \mathrm{cm}^{2}$ from exponentially growing cells (3 days after plating), whereas Dr. Buchwald (1) subcultured confluent dishes at 1:8 dilution; (2) we did not feed our cells during the 11 days of culture, whereas the cells of the original study (1) were fed every 3 days. Nonetheless, the growth curves of these cells were very similar to the growth curves illustrated in the first study (1); cell number increased for 8 days before leveling off between 8 and 11 days. The final averaged density of the cells also was similar: $44,000 \pm 8,000$ cells $/ \mathrm{cm}^{2}$ in the first study (1) and $56,000 \pm 25,000$ ( \pm S.D.) cells $/ \mathrm{cm}^{2}$ here.

We also measured cyclic AMP content after 15 and $60 \mathrm{~min}$ of $10 \mu \mathrm{M} \mathrm{PGE}_{1}$ with $7 \mathrm{mM}$ Ro20-1724 or IBMX. With these confluent cultures, the averaged CF response was in all four situations within $15 \%$ of the averaged response of normal cells of about 5 nmoles cAMP per $10^{6}$ cells. Buchwald (1) observed a similar lack of difference between $\mathrm{CF}$ and normal cells in their response to $\mathrm{PGE}_{1} 60 \mathrm{~min}$ after exposure to $1.0 \mu \mathrm{M} \mathrm{PGE}_{1}$ plus $0.7 \mathrm{mM}$ Ro201724.

\section{ACCUMULATION OF CYCLIC AMP DURING EXPONENTIAL GROWTH}

Buchwald (1) measured an increased response to isoproterenol by two strains of CF cells when tested at 2, 4, and 7 days as well as at 11 days. We compared CF and normal fibroblasts 3 days after plating on two occasions (Tables 2 and 3). We grew cells in the growth medium described in "Materials and Methods" with 15 or $20 \%$ fetal calf serum. Table 2 contains data pertaining to an experiment done with $20 \%$ fetal calf serum on 23 of these strains. Table 3 presents an experiment examining 19 strains during growth in $15 \%$ fetal calf serum.

We found very similar averages for all measurements of cyclic AMP accumulation in response to $10 \mu \mathrm{M}$ isoproterenol. With 0.2 mM IBMX (Table 2), no difference in the average cyclic AMP content was seen at 2 to 5 or $15 \mathrm{~min}$ whether one expressed the content per $\mathrm{mg}$ protein or per $10^{6}$ cells $(P>0.4)$. With $0.5 \mathrm{mM}$ IBMX (Table 3), no difference in average cyclic AMP content was seen at 10 or $15 \mathrm{~min}$ regardless of the manner of expression $(P>$ $0.7)$.

\section{INITIAL RATE OF ACCUMULATION OF CYCLIC AMP}

To test for a differential effect of isoproterenol on adenylate cyclase which might be masked by differing rates of desensitization (13), cyclic AMP degradation, or cyclic AMP secretion, we measured initial rates of accumulation of cyclic AMP in intact cells after stimulation with $10 \mu \mathrm{M}$ isoproterenol. By adding $0.5 \mathrm{mM}$ IBMX simultaneously with $10 \mu \mathrm{M}$ isoproterenol and measuring at times less than $1 \mathrm{~min}$, an apparently linear accumulation of cyclic AMP was produced. Without phosphodiesterase inhibitor, the response was decidedly nonlinear by $40 \mathrm{sec}$ for most of the 23 strains tested. We found that simultaneous addition of agonist and IBMX or Ro20-1724 led to faster initial rates when compared with a preincubation of phosphodiesterase inhibitor followed by agonist. (These two inhibitors were of approximately equal efficacy at increasing the accumulation of cyclic AMP after isoproterenol stimulation of exponentially growing cells (GM498). Table 1 shows they are also of similar efficacy with confluent cultures.) 
Table 2. Accumulation of cyclic AMP by exponentially growing cells

\begin{tabular}{|c|c|c|c|c|c|c|c|}
\hline & Strain & $\begin{array}{c}\text { Doubling } \\
\text { time (hr) }\end{array}$ & $\begin{array}{l}\text { mg protein/ } \\
10^{6} \text { cells }\end{array}$ & \multicolumn{2}{|c|}{ Cyclic AMP at 2 and $5 \mathrm{~min}$} & \multicolumn{2}{|c|}{ Cyclic AMP at $15 \mathrm{~min}^{1}$} \\
\hline $\mathrm{CF}$ & 142 & 24.9 & 0.37 & 0.070 & 0.19 & 0.086 & 0.23 \\
\hline $\mathrm{CF}$ & 1014 & 26.6 & 0.50 & 0.081 & 0.16 & 0.034 & 0.07 \\
\hline $\mathrm{CF}$ & 768 & 19.8 & 0.35 & 0.090 & 0.26 & 0.070 & 0.20 \\
\hline $\mathrm{CF}$ & 770 & 26.1 & 0.56 & 0.225 & 0.40 & 0.236 & 0.42 \\
\hline $\mathrm{CF}$ & 997 & 71.4 & 0.88 & 0.190 & 0.22 & & \\
\hline $\mathrm{CF}$ & 851 & 43.6 & 1.17 & 0.278 & 0.24 & 0.124 & 0.11 \\
\hline $\mathrm{CF}$ & 1011 & 41.6 & 0.73 & 0.123 & 0.17 & 0.107 & 0.15 \\
\hline $\mathrm{CF}$ & 1707 & 32.3 & 0.55 & 0.200 & 0.36 & 0.192 & 0.34 \\
\hline $\mathrm{CF}$ & 999 & 37.7 & 0.53 & 0.121 & 0.23 & 0.139 & 0.26 \\
\hline \multicolumn{2}{|c|}{ Mean \pm S.E. } & $33.8 \pm 4.0$ & $0.58 \pm 0.07$ & $0.142 \pm 0.020$ & $0.26 \pm 0.04$ & $0.110 \pm 0.020$ & $0.22 \pm 0.04$ \\
\hline $\mathrm{N}$ & 495 & 31.4 & 0.54 & 0.088 & 0.16 & 0.074 & 0.14 \\
\hline $\mathrm{N}$ & 500 & 37.2 & 0.37 & 0.088 & 0.24 & 0.037 & 0.10 \\
\hline $\mathrm{N}$ & 409 & 38.1 & 0.92 & 0.108 & 0.12 & 0.094 & 0.10 \\
\hline $\mathrm{N}$ & 497 & 37.4 & 0.82 & 0.170 & 0.21 & 0.292 & 0.36 \\
\hline $\mathrm{N}$ & 1582 & 33.3 & 0.52 & 0.066 & 0.13 & 0.026 & 0.05 \\
\hline $\mathrm{N}$ & 1651 & 30.3 & 0.44 & 0.114 & 0.25 & 0.151 & 0.34 \\
\hline $\mathrm{N}$ & 1652 & 29.7 & 0.41 & 0.063 & 0.15 & 0.033 & 0.08 \\
\hline \multicolumn{2}{|c|}{ Mean \pm S.E. } & $31.3 \pm 1.4$ & $0.53 \pm 0.05$ & $0.118 \pm 0.026$ & $0.24 \pm 0.06$ & $0.111 \pm 0.035$ & $0.21 \pm 0.07$ \\
\hline
\end{tabular}

'nmoles cyclic AMP. Cells were seeded in the medium described in "Materials and Methods" with 20\% fetal calf serum but otherwise as in Table 1. They were challenged at about $70 \mathrm{hr}$ with $10 \mu \mathrm{M}$ isoproterenol and $0.2 \mathrm{mM}$ IBMX. Doubling time was calculated between 50 and $80 \mathrm{hr}$. Values are the averages of triplicate samples.

Table 3. Accumulation and initial rate of accumulation of cyclic AMP in exponentially growing cells

\begin{tabular}{|c|c|c|c|c|c|c|c|c|}
\hline & \multirow[b]{2}{*}{ Strain } & \multirow{2}{*}{$\begin{array}{l}\text { Doubling } \\
\text { time (hr) }\end{array}$} & \multirow{2}{*}{$\begin{array}{c}\text { mg protein/ } \\
10^{6} \text { cells }\end{array}$} & \multicolumn{4}{|c|}{ Accumulation of cyclic AMP ${ }^{1}$} & \multirow{2}{*}{$\begin{array}{c}\text { Initial rate } \mathrm{re}^{2} 0 \text { to } 50 \\
\mathrm{sec}(\mathrm{nmoles} / \mathrm{min} / \mathrm{mg} \\
\text { protein) }\end{array}$} \\
\hline & & & & Per $10^{6}$ cells & Per mg protein & Per $10^{6}$ cells & Per mg protein & \\
\hline $\mathrm{CF}$ & 142 & 24.1 & 0.64 & 0.35 & 0.55 & 0.29 & 0.46 & 0.18 \\
\hline $\mathrm{CF}$ & 1013 & 24.8 & 0.57 & 0.14 & 0.25 & 0.07 & 0.12 & 0.23 \\
\hline $\mathrm{CF}$ & 1014 & 29.3 & 0.68 & 0.15 & 0.22 & 0.15 & 0.22 & 0.16 \\
\hline $\mathrm{CF}$ & 998 & 57.4 & 1.18 & 0.25 & 0.21 & 0.13 & 0.11 & 0.10 \\
\hline $\mathrm{CF}$ & 1957 & 24.6 & 0.57 & 0.27 & 0.48 & 0.25 & 0.43 & 0.21 \\
\hline $\mathrm{CF}$ & 1959 & 23.5 & 0.69 & 0.35 & 0.50 & 0.29 & 0.42 & 0.19 \\
\hline $\mathrm{CF}$ & 1707 & 27.1 & 0.81 & 0.71 & 0.88 & 0.53 & 0.65 & 0.32 \\
\hline $\mathrm{CF}$ & 999 & 31.9 & 0.85 & 0.48 & 0.56 & 0.42 & 0.49 & 0.22 \\
\hline \multicolumn{2}{|c|}{ Mean \pm S.E. } & $29.7 \pm 3.2$ & $0.74 \pm 0.06$ & $0.344 \pm 0.058$ & $0.464 \pm 0.065$ & $0.287 \pm 0.053$ & $0.385 \pm 0.059$ & $0.198 \pm 0.018$ \\
\hline $\mathrm{N}$ & 2037 & 29.5 & 0.88 & 0.22 & 0.25 & 0.17 & 0.19 & 0.14 \\
\hline $\mathrm{N}$ & 495 & 40.3 & 0.75 & 0.29 & 0.39 & 0.27 & 0.36 & 0.18 \\
\hline $\mathrm{N}$ & 1582 & 32.0 & 1.25 & 0.31 & 0.25 & 0.30 & 0.24 & 0.12 \\
\hline $\mathrm{N}$ & 1651 & 25.9 & 0.85 & 0.52 & 0.61 & 0.55 & 0.65 & 0.21 \\
\hline $\mathrm{N}$ & 1652 & 25.2 & 0.79 & 0.08 & 0.10 & 0.11 & 0.14 & 0.10 \\
\hline \multicolumn{2}{|c|}{ Mean \pm S.E. } & $29.5 \pm 1.8$ & $0.85 \pm 0.07$ & $0.343 \pm 0.081$ & $0.423 \pm 0.107$ & $0.310 \pm 0.071$ & $0.383 \pm 0.094$ & $0.191 \pm 0.035$ \\
\hline
\end{tabular}

${ }^{1}$ nmoles cyclic AMP. Cells were seeded as in Table 2 but with $15 \%$ fetal calf serum. They were challenged at about 70 hr with $10 \mu$ M isoproterenol and $0.5 \mathrm{mM}$ IBMX. Doubling time was calculated between 34 and $81 \mathrm{hr}$. Values are the averages of triplicate samples.

${ }^{2}$ Cells were grown and challenged as described for the measurement of accumulation but cyclic AMP was measured at times of less than 1 min. The initial rates were approximated by linear least squares analysis of the 18 measurements. Figure 1 illustrates some of the data. 
Figure 1 illustrates the response of four strains to $10 \mu \mathrm{M}$ isoproterenol and $0.5 \mathrm{mM}$ IBMX (GM1707, 998, 323, and 1652). These strains represent the fastest and slowest accumulators from the sets of CF and normal strains. The last column of Table 3 contains the rates for each cell strain (estimated by linear least squares fit). Again, the average responses are nearly identical for $\mathrm{CF}$ and normal cells at 0.198 and $0.191 \mathrm{nmoles} / \mathrm{min} / \mathrm{mg}$ protein, respectively.

\section{CONTROLS ON REPRODUCIBILITY}

Various kinds of controls were run to test the accuracy and precision of these measurements. Cell strains were not sequenced in blocks of CF or normal strains but rather alternated throughout the seedings, challenge by agonist, purification, and cyclic AMP assay. Two or generally three samples were generated for each condition. The range of triplicates was acceptable; e.g., the average standard deviation of the 10 min values in Table 3 was $8 \%$.

As a check on the precision of the cyclic AMP assay itself, we reassayed the 19 samples of GM316 for cyclic AMP content at 10 and $15 \mathrm{~min}$ and initial rate of accumulation (Table 3). We found an average $15 \%$ difference and an initial rate of 0.20 nmoles per $\mathrm{mg}$ protein per min compared to the original estimate of 0.23 .

As a measure of the reproducibility of the entire procedure within an experiment, one ampule of GM2037 was thawed and passaged into two dishes at identical density. On day zero, suitable samples were prepared from each of these dishes and stimulated for cyclic AMP production on day 3. The duplicate not shown in Table 3 gave values within $8 \%$ of those shown for the isoproterenol-stimulated cyclic AMP accumulation at 10 and $15 \mathrm{~min}$. The duplicate initial rate measurement was based on only six points rather than the usual 18 points because of a loss of samples; it was $18 \%$ different.

In the experiment of Table 2 only, the strains were carried in two groups begun on succeeding days, with strain GM142 in both
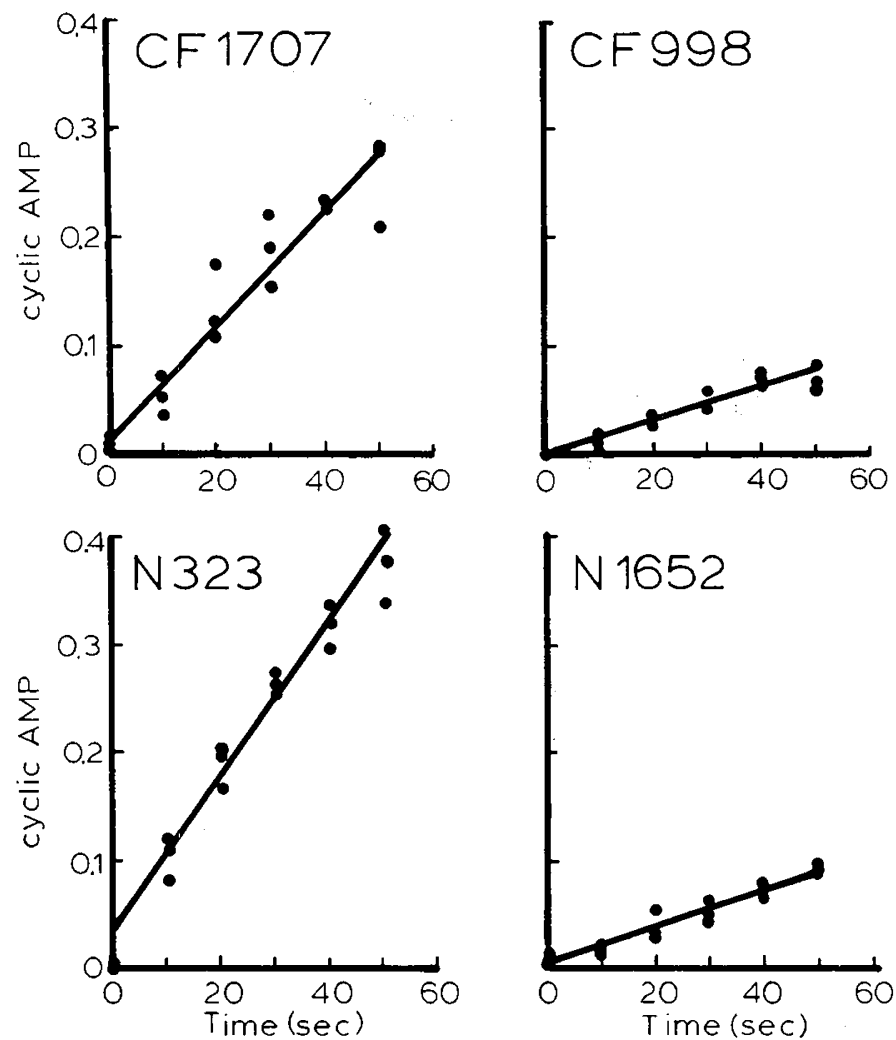

Fig. 1. The initial rates of intracellular cyclic AMP accumulation, $\mathrm{nmoles} / \mathrm{mg}$ protein versus time in seconds. Cells were seeded and challenged as in Table 3. Symbols represent a single sample. groups. This allowed a spot-check on the values derived for this one strain. We observed 20\% differences in cyclic AMP per mg protein at 2 to $5 \mathrm{~min}$ and at $15 \mathrm{~min}$ in the presence of $0.2 \mathrm{mM}$ IBMX.

A final and perhaps most important check on the conclusions from the experiments is that 17 of the strains were thawed and grown once for the experiments of Table 2 and again for that of Table 3. The only differences in the protocols leading to the 15 min values after $10 \mu \mathrm{M}$ isoproterenol are the small difference in serum content of the growth medium and the concentrations of IBMX used, 0.2 versus $0.5 \mathrm{mM}$. Inasmuch as other experiments have indicated that phosphodiesterase inhibition is not complete at $0.2 \mathrm{mM}$ IBMX, we should expect a higher response in each strain in Table 3 . In fact, each of the 17 strains showed a reasonable increase in response except GM1959, which showed a 14\% drop. The doubling times for these 17 cell strains were also quite reproducible between the two experiments except for GM998 which is typically a slow grower but was measured as a fast grower in the experiment in Table 2 . The average doubling time for the other eight CF cells was $27.9 \pm 1.9 \mathrm{hr}( \pm$ S.E.) in Table 2 and 26.9 $\pm 1.3 \mathrm{hr}$ in Table 3 ; the values for the eight normal cells were 28.9 \pm 1.1 in Table 2 and $28.7 \pm 1.9$ in Table 3 .

\section{DISCUSSION}

We recognize that our system of comparing cells which originated from different areas of human skin and were grown by different people for different lengths of time in different media before being sent to the Institute for Medical Research is not ideal. It would have been a better experimental design to have used strains which originated in just one laboratory using the same origination procedure for each strain. However, with a large enough sampling of the two populations (here $13 \mathrm{CF}$ and 12 normal strains), most of these differences would be represented in both populations. We obtained strains such that the average ages and passage numbers would be similar (Table 1). The average doubling times (a parameter of large variation) turned out to be similar as has been found in most recent comparisons of CF and normal fibroblasts [summarized by Shapiro et al. (12)]. The similarity in doubling time existed in spite of the differing histories of the cell strains; thus, it seems reasonably safe to generalize other observations on these sets of cells. The results presented show that for these sets of normal and CF skin fibroblasts there were no significant differences in their responses to isoproterenol or to $\mathrm{PGE}_{1}$ in content of cyclic AMP at two different times whether the cells were growing exponentially (Tables 2 and 3 ) or were already confluent (Table 1). All strains responded similarly to the presence of two types of phosphodiesterase inhibitor. The averaged initial rates of the responses to isoproterenol in exponentially growing cells were also similar for the two sets of strains (Table 3 ).

Any one of these data sets is sufficiently extensive and precise to rule out the possibility that we are missing a large (100\%) increase in CF responsiveness to isoproterenol. By calculating the $t$ statistic for two means (9) for the accumulations of cyclic AMP after 15 min of isoproterenol and IBMX expressed per mg protein, we find that a $25 \%$ difference is possible with a probability of 0.30 (Table 1), 0.50 (Table 2), and 0.37 (Table 3). However, a 100\% difference is only probable to an extent of $0.01,0.02$, and 0.003 , respectively, whereas a $200 \%$ difference has less than 0.0001 probability in each case. The rate data from Table 3 rule out a $100 \%$ difference at the 0.0001 level.

This report is the fifth published article (excluding abstracts) on the accumulation of cyclic AMP by CF and normal fibroblasts in response to isoproterenol and $\mathrm{PGE}_{1}$. The clear consensus of the reports published after the original observation (1) is that there is no large difference in the responses of these two types of cells. No one has reported any statistically significant differences in response to $\mathrm{PGE}_{1}$. The largest difference in isoproterenol-induced response ratio (CF:N) was seen in the original report on this subject (1); a ratio of 3.42 was observed based on five cell strains 
of each type ( $n=5$ ) with no overlap between types. No other results have approached this ratio: Buchwald and Mapleson (2) found a ratio of $1.45(n=10)$; Roscher et al. (11) found a ratio of $1.70(n=6)$; Davis et al. (6) found a ratio of about $1.0(n=10)$, although their previous abstract (5) using six of these 10 strains showed a ratio of $0.34(n=6)$. We found a ratio of $1.0(n=12)$ in the present study. The average ratio for all studies is approximately $1.5(n=43)$. There are a number of possible explanations for the apparent discrepancies. First, it is possible that Buchwald's 1976 conditions (1) were never again reproduced exactly, even by Buchwald and Mapleson (2). However, with four research groups working independently, three of which have attempted to follow the original procedure (1), it seems likely that these conditions were closely simulated, arguing against this explanation. Thus, it seems probable that the original work by chance involved five high responding $C F$ strains and five low-responding normal strains. Then what is the correct average ratio, i.e., the ratio of responses if all CF and normal strains were compared? Roscher et al. (11) have presented evidence for a true average higher than 1.0. After 4 days of serum deprivation (intended to synchronize the cells in G-1), they saw an average ratio of $1.7 \pm 0.60$ S.D. based on 20 determinations on six pairs of cells, a value expected by chance with a probability of only 0.001 according to their paired $t$ test. Did they observe this ratio because of a chance selection of strains or because of their different experimental protocol? They list the important factors in their protocol as passage number, cell density, time after subculture, serum concentration, and stage of the cell cycle. However, all of these conditions have been considered by others. Each investigation has utilized $\mathrm{CF}$ and normal cells at the same passage number (here six to seven passages) and donor age (here 11 to 12 years). We have been careful with cell density, always starting cells at a density of $2500 / \mathrm{cm}^{2}$ on day 0 . By day 3 , when the responses were measured, all cell strains were growing exponentially at similar densities (about $10,000 / \mathrm{cm}^{2}$ ), a density below that causing cell density inhibition of growth and less than the density of $20,000 / \mathrm{cm}^{2}$ used by Roscher et al. (11). The time after subculture at which response was measured has been standardized by everyone (here $70 \mathrm{hr}$ ). The initial serum concentration has, of course, been identical between $C F$ and normal strains; the possibility that different strains consumed factors in serum at different rates was obviated by frequent changes of medium or by early measurement (here 70 hr) with low densities of cells. The other potentially important effect of serum and of other medium components would be on the response itself directly. Roscher et al. (11) washed three times with serum-free medium before testing for response. Buchwald and Mapleson (2) washed once, and Davis et al. (6) washed three times with phosphate-buffered saline. We did not wash cells although the old medium was removed before isoproterenol in HEPESbuffered medium was added. We estimate that the concentrations of components of the old medium were reduced to about $2 \%$. Roscher et al. (11) serum-starved the cells in the hope of then being able to measure all strains at the same stage in the cell cycle (G-1). Although we agree that cell cycle stage may be important in the response of the cells, we have controlled for this by ensuring exponential growth of all strains, causing approximately equal fractions of cells in each cell stage and in each subdivision of each stage as well. In spite of the intent of the synchronization procedure, it is not clear to us that serum starvation increases the uniformity of the response to isoproterenol. From the statement of Roscher et al. (11) that measurable incorporation of thymidine was occurring, clearly not all cells were in G-1. Even those cells in G-1 may not be at the same point in G-1 and those at the same points will not have been there for equal lengths of time; cell response could possibly differ both according to the cell's position in G-1 and the length of time in G-1. Furthermore, they presented no evidence that different strains react similarly to serum starvation in terms of cell death or rate of protein synthesis.

Thus, we believe that Roscher et al. (11) observed a ratio of response higher than 1.0 not because of any uniqueness in their methods of measuring response to isoproterenol but rather because they happened to select high-responding CF strains and lowresponding normal strains. All of our averaged results (Tables 1 to 3) point to no difference between $C F$ and normal strains. However, if we had by chance selected only the five CF strains GM768, 998, 1959, 1707, and 999 and compared them only to the normal strains GM316, 323, 498, 2037, 495, we would have found an average ratio of 2.4 (Table 1, Ro20-1724). If we had by chance selected five low-responding CF and five high-responding normal strains, we would have gotten an equally "significant" ratio of 0.3 .

All four groups investigating the isoproterenol responses of fibroblasts have seen large variation between strains; the three other groups have seen large variation for the same strain measured on different days. As presented in "Controls on Reproducibility," we found semiquantitative reproduction of the response of each strain. The factors which we think may be important in this respect, listed in decreasing order of supposed importance, are: (1) trypsinization using $0.05 \%$ trypsin at room temperature (after one rinse with GHCKS) of cells which are in exponential growth; (2) freeing of cells by streaming growth medium over them rather than waiting for trypsin to release all cells or using a higher concentration of trypsin; (3) use of a low initial cell density and of a type and volume of medium which together ensure fast exponential growth over a prolonged period of time; (4) measurement of response during this exponential growth; (5) purifying of cyclic AMP standards and samples before assaying them.

We are not aware of any evidence that fibroblasts of CF patients function abnormally in vivo (14). Thus, study of fibroblasts would seem to be useful only as a convenient model system for CF. Given the high incidence of this life-threatening disease and the near total ignorance of its biochemical causes, any clear objectively measured difference between $\mathrm{CF}$ and normal fibroblasts would be welcomed by CF researchers as a clue to the basis of the disease process that is expressed overtly by other cell types and possibly as a method for prenatal diagnosis if the difference could also be observed in cells from amniotic fluid. (See Refs. 3 and 4 for thoughtful discussion of the utility of fibroblasts in CF research.) However, if there is a useful difference between the average CF fibroblast and the average normal fibroblast, it does not seem to be in their responses to $\beta$-adrenergic receptor agonists or to $\mathrm{PGE}_{1}$.

\section{REFERENCES AND NOTES}

1. Buchwald, M.: Abnormal levels of $3^{\prime}: 5^{\prime}$-cyclic AMP in isoproterenol-stimulated fibroblasts from patients with cystic fibrosis. Proc. Natl. Acad. Sci. U. S. A., 73: 2899 (1976)

2. Buchwald, M., and Mapleson, J. L.: Adenosine $3^{\prime}: 5^{\prime}$-cyclic AMP in fibroblasts from patients with cystic fibrosis and its relationship to secretion. Mod. Probl. Paediatr., 19: 165 (1977).

3. Buchwald, M., and Riordan, J. R.: Cyclic nucleotides and cystic fibrosis. Adv. Cyclic Nucleotide Res., 12: 243 (1980).

4. Davis, P. B., and di Sant'Agnese, P. A.: A Review. Cystic fibrosis at forty-quo vadis? Pediatr. Res., 14: 83 (1980).

5. Davis, P. B., and Hill, S. C.: Adenosine $3^{\prime}: 5^{\prime}$-cyclic monophosphate (cAMP) production in cystic fibrosis (CF) fibroblasts. Am. Rev. Respir. Dis. (Abstract), 117: 328 (1978).

6. Davis, P. B., Hill, S. C., and Ulane, M. M.: Hormone-stimulated cyclic AMP production by skin fibroblasts cultured from healthy persons and patients with cystic fibrosis. Pediatr. Res., 14: 863 (1980).

7. Elmore, E., and Swift, M.: Growth of human skin fibroblasts in dialyzed fetal bovine serum. In Vitro, 13: 837 (1977)

8. Harper, J. F., and Brooker, G.: Femtomole sensitive radioimmunoassay for cyclic AMP and cyclic GMP after 2'0 acetylation by acetic anhydride in aqueous solution. J. Cyclic Nucleotide Res., 1: 207 (1975).

9. HP-25 Application Programs. Hewlett-Packard, p. 124 (Hewlet-Packard, Cupertino, CA, 1975).

10. Lowry, O. H., Rosenbrough, N. J., Farr, A. L., and Randall, R. J.: Protein measurement with the Folin phenol reagent. J Biol Chem 193.265 (1951)

11. Roscher, A. A., Schmid, A. J., Hadorn, B., and Wiesmann, U. N.: Enhanced adenosine $3^{\prime}: 5^{\prime}$-monophosphate response to beta-adrenergic stimulation in cystic fibrosis fibroblasts after removal of conditioned medium. Pediatr. Res., I4: 261 (1980).

12. Shapiro, B. L., Lam, L. F.-H., and Fast, L. H.: Premature senescence in cultured skin fibroblasts from subjects with cystic fibrosis. Science (Wash. D. C.), 203: 1251 (1979).

13. Terasaki, W. L., Brooker, G., de Vellis, J., Inglish, D., Hsu, C.-Y., and Moylan, R. D.: Involvement of cyclic AMP and protein synthesis in catecholamine refractoriness. Adv. Cyclic Nucleotide Res., 9: 33 (1978). 
14. Tissue Culture Approaches to the Study of Cystic Fibrosis. Cystic Fibrosis Conference Reports, Vol. 2, No. 1 (1978).

15. Zeilig, C. E., and Goldberg, N. D.: Cell-cycle-related changes of 3':5'-cyclic GMP levels in Novikoff hepatoma cells. Proc. Natl. Acad. Sci. U. S. A., 74: 1052 (1977).

16. Requests for reprints should be addressed to: James B. Kurz, Department of
Pharmacology, 1108 Faculty Laboratory Office Bldg., University of North Carolina, Chapel Hill, NC 27514 (USA).

17. Dr. Kurz was supported by grants MY402 and MY466 of the United States Cystic Fibrosis Foundation.

18. Received for publication November 19,1979

19. Accepted for publication August 13, 1980. Neuropsychiatric Institute, UCLA, Los Angeles, CA. Symposium Co-Chairmen: Melvin D. Levine, M.D. and Paul Satz, Ph.D. Appropriate Category 1 CME Credits toward the American Medical Association Physician's Recognition Award and the American Academy of Pediatrics PREP Required Credits will be given. For further information contact: Steven Sawchuk, M.D., Johnson \& Johnson Baby Products Co., Grandview Road, Skillman, NJ 08558 (201) 874-1645 or 1646. 